\title{
Distriktslegen i Aksel Sandemoses Tjærehandleren
}

\begin{abstract}
Aksel Sandemose (1899-1965) var en av de mest produktive og innflytelsesrike, men også mest omdiskuterte norske forfattere gjennom tidene. I romanen Tjærehandleren tegnes et interessant portrett av en distriktslege.
\end{abstract}

Torbjørn Vatnaland

tovatna@online.no

Lars Vatnaland

I romanen Tjoerehandleren fra 1945 møter vi ekteskapssvindleren Audun Hamre, som under dekke av å være en alminnelig handelsreisende i tjære, stjeler så mye penger fra giftelystne kvinner at han kan bygge seg sin drømmebolig langt fra allfarvei og derved realisere sitt livsmål - et isolert og enslig liv i trygghet (1). Audun kan leses som en omskrivning av Odin (2, side 399). Det er derfor nærliggende å oppfatte Hamre som en allusjon til Tors hammer. Audun Hamre, med sin kløkt og handlekraft, men også hensynsløshet og brutalitet, kan således ses som en syntese av de to mektigste norrøne gudene.

For å kontrastere hovedpersonen Hamre velger Sandemose en person med allmenn tillit og høy sosial status - en distriktslege med det megetsigende navnet Verner Vestad - han som beskytter mot smerter/veer. Vestad er 49 år gammel. Han bestemte seg tidlig i livet for å bli distriktslege og setter sin ære i å fylle embetsstillingen så godt som mulig. Yrkesrollen klarer han, men ekteskapet og familielivet har for lengst strandet.

\section{Alter ego}

Allerede i åpningsscenen understrekes de to mennenes slektskap, når de intetanende nesten støter på hverandre en kveldsstund i en regnvåt skog. Hamres marerittaktige minner om en kvinne han har stjålet fra og som har listet seg inn på ham for å drepe ham med en hammer (sic!), blir overført til Vestad. Man mer enn aner kraften som binder disse to mennene sammen.

Hamre har, i motsetning til Vestad, foretatt klare valg for hvordan livet hans skal se ut, og han er en aktiv deltaker i og medskaper av sitt eget liv. I så måte er beskrivelsen av Audun Hamre en mesterlig studie i menneskets søken etter en formel som lindrer ensomhetsfølelsen og fremmer den kompenserende storhetsfølelsen. Sandemose har her utførligst og mest inntrengende tegnet portrettet av ensomhetens overmenneske (3, side 212).
Vestad, derimot, er intet overmenneske. Han lar seg rive med av hendelsenes strøm når den griper tak i ham. Han er på nippet til å bryte ut av sitt havarerte ekteskap, men faller tilbake i folden, og er på mange måter en ikke-deltaker i sitt eget liv. Med eksistensialistiske termer kan Hamre således sies å leve et tragisk, men fritt liv, mens Vestad lever et trivielt og ufritt liv.

Når Hamre og Vestad endelig møtes ansikt til ansikt, oppstår gjensidig sympati. Dette må ses i lys av at boken egentlig handler om en dobbeltperson (2, side 393) og at de to representerer ulike sider av Sandemose selv (2, side 402). Med Tjoerehandleren avslører
Sandemose mer åpent enn noen gang før sin egen sammensatte natur. Distriktslege Vestad er forfatterens sosialt aksepterte - og Hamre hans sosialt ikke-aksepterte - alter ego. Ikke noe sted har Sandemose lagt ned så mye av seg selv som i denne romanen og dens personskildringer (2, side 402). I et utvidet perspektiv representerer de to romanfigurene også motsetningen mellom alle menneskers byggende og nedbrytende krefter.

\section{Dr. Jekyll}

Litteraturhistorisk er ikke distriktslege Vestad den første legeskikkelsen som inngår i en ond/god-dobbeltpersonlighet. Den

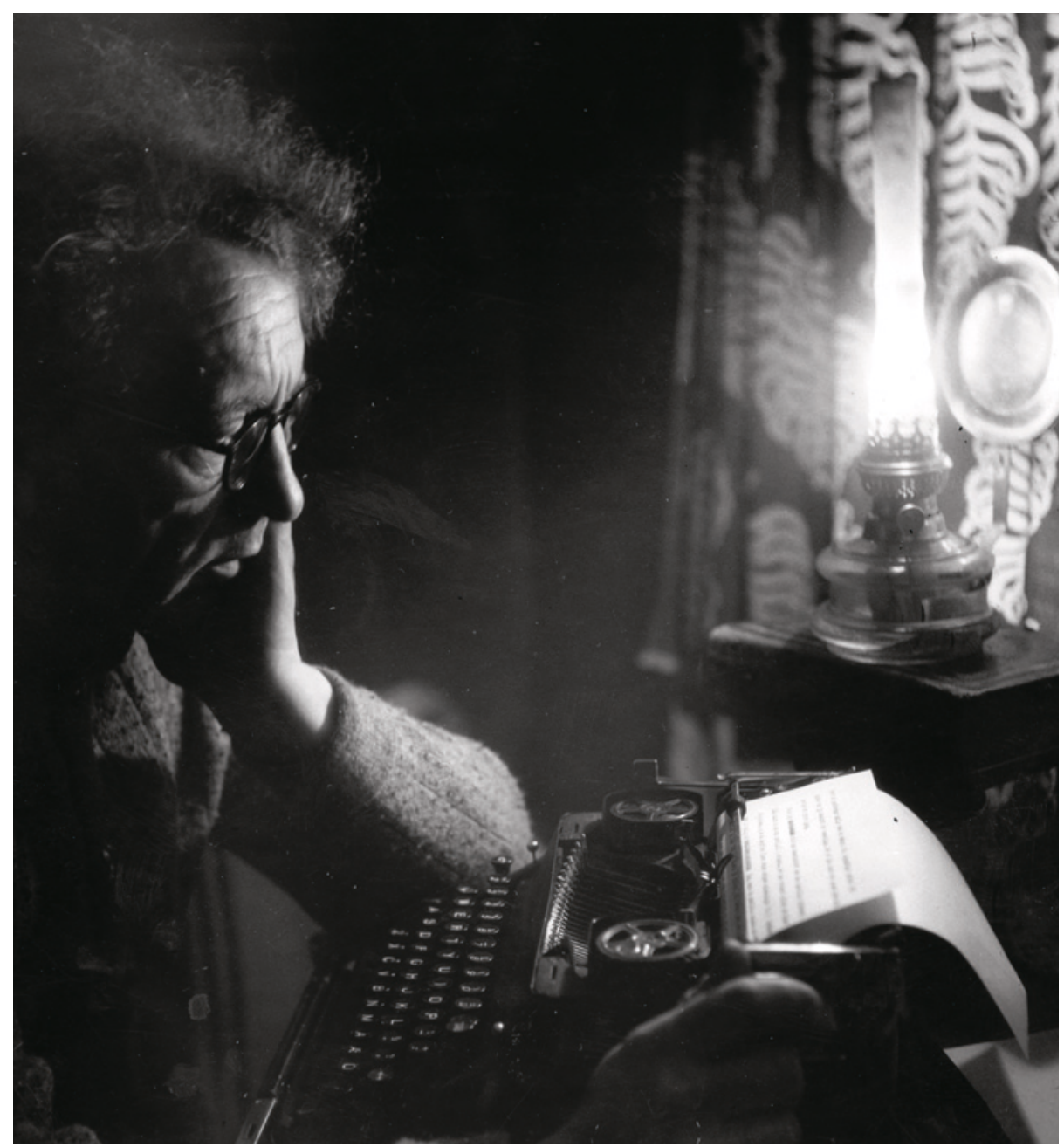

Aksel Sandemose, 1947. Foto: Th. Skotaam/Aktuell/Scanpix 
mest kjente er kanskje Robert Louis Stevensons (1850-94) veltilpassede og elskelige London-lege Dr. Jekyll, som eksperimenterer seg frem til en trylledrikk som omskaper ham til den brutale og hensynsløse Mr. Hyde (4). På denne måten tror doktoren at han kan leve ut sine grusomme sider uten å måtte ta konsekvensene av det. Stevenson velger en legeskikkelse som er svært ulik sin motpol, slik at kontrasten mellom dem blir nærmest maksimal. Sandemose, derimot, har flettet inn i handlingen en rekke parallelle faktorer mellom Hamre og Vestad. Dette gjør at de utvendig sett fremstår som like. Distriktslegen får på den måten en alibifunksjon for den farlige og sjarmerende Hamre. I et spissformulert øyeblikk kan man kanskje gå så langt som å si at distriktslege Vestad er en norsk Dr. Jekyll, i en mer realistisk fremtoning enn i Stevensons sciencefictionroman.
Med sin høyst virkelighetsnære utforskning av menneskesinnets irrganger, kompleksitet og motsetningsfylte innhold, går Tjcerehandleren virkelig under huden på leseren. Handlingen drives mesterlig fremover ved en stegvis avdekning av den tragiske bakgrunnen for at Hamre er blitt den han er.

Denne tynne boken på bare 138 sider fortjener avgjort vår oppmerksomhet. Dualismen ond og god er et evig aktuelt tema, og det er lenge mellom hver gang man finner en så handlingsmettet skildring kombinert med så mange dyptloddende refleksjoner, skarpsindige observasjoner og løsslupne formuleringer.

Torbjørn Vatnaland (f. 1943)

er spesialist i psykiatri og pensjonert. Forfatter har fylt ut ICMJE-skjemaet og oppgir ingen interessekonflikter.

\section{Lars Vatnaland (f. 1977)}

er journalist og seniorrådgiver i Klima- og miljødepartementet.

Forfatter har fylt ut ICMJE-skjemaet og oppgir ingen interessekonflikter.

Litteratur

1. Sandemose A. Tjærehandleren. Oslo: Aschehoug, 1945.

2. Sandemose J. Flyktningen. Aksel Sandemose en biografi. Oslo: Aschehoug, 2004

3. Nordberg CE. Sandemose. En biografi. Oslo: Aschehoug, 1967

4. Stevenson RL. The strange case of Dr. Jekyll and Mr. Hyde. London: Longmans, Green \& co, 1886

Mottatt 24.10. 2014, første revisjon innsendt 27.5. 2015, godkjent 29.6. 2015. Redaktør: Are Brean. 